\title{
Article \\ Seed Quality of Lablab Bean (Lablab purpureus) as Influenced by Seed Maturity and Drying Methods
}

\author{
Nurul Fatin Hanani Hanapiah, Uma Rani Sinniah *(D) and Martini Mohammad Yusoff
}

check for updates

Citation: Hanapiah, N.F.H.; Sinniah, U.R.; Yusoff, M.M. Seed Quality of Lablab Bean (Lablab purpureus) as Influenced by Seed Maturity and Drying Methods. Agronomy 2022, 12, 363. https:// doi.org/10.3390/agronomy12020363

Academic Editor: Cristina Patanè

Received: 15 December 2021

Accepted: 27 January 2022

Published: 31 January 2022

Publisher's Note: MDPI stays neutral with regard to jurisdictional claims in published maps and institutional affiliations.

Copyright: (C) 2022 by the authors. Licensee MDPI, Basel, Switzerland. This article is an open access article distributed under the terms and conditions of the Creative Commons Attribution (CC BY) license (https:// creativecommons.org/licenses/by/ $4.0 /)$.

\author{
Department of Crop Science, Faculty of Agriculture, Universiti Putra Malaysia, \\ Serdang 43400, Selangor, Malaysia; fatinhanani.nurul@gmail.com (N.F.H.H.); martinimy@upm.edu.my (M.M.Y.) \\ * Correspondence: umarani@upm.edu.my; Tel.: +60-172551500 or +60-397694839
}

\begin{abstract}
The lablab bean or 'Kacang sepat' is a food crop originating from India and is commonly found in tropical areas such as Indonesia, Thailand and the Philippines due to its adaptability. However, in Malaysia, lablab is grown as a backyard crop, and the area cultivated with this crop is still limited. Lablab has the potential to become a commercial vegetable crop in Malaysia due to its high protein content (18-25\%). Therefore, to increase lablab cultivation, good quality seeds are a prerequisite. A key factor in the production of quality seeds is the ideal harvest time of the pods during seed development and maturation and based on identifiable characteristics. The first part of this study was conducted to assess the physical characteristics of lablab pods and seeds of the cultivar Highworth (MDI 12842). Plants were grown using standard cultural practices. Pods and seeds were collected at ten different maturity stages $(5,10,15,20,25,30,35,40,45$, and 50 days after anthesis (DAA)). Pods and seeds showed a significant difference in size and colour at different maturity stages. Seeds harvested at 20 DAA had maximum pod and seed size. The seeds attained physiological maturity (PM) at 30 DAA when the pod colour is light reddish brown and, after being subjected to sun and oven drying, gave maximum germination percentages of $89 \%$ and $91 \%$, respectively, while fresh seeds had only $78 \%$ germination. Results indicated that the germination percentage of lablab improved, regardless of the drying method used. Therefore, the lablab bean pod colour is a suitable indicator to be used as an easy method for the identification of the best time for pod harvesting for seed production.
\end{abstract}

Keywords: germination; lablab; maturity stage; physiological maturity; seed quality

\section{Introduction}

Beans, often known as legumes, are the second most important food source in the human diet. They are a rich source of proteins, carbohydrates, fibre, vitamins and minerals. Long beans, French beans and four-angled beans are among the most popular ones. According to Rudrappa [1], the protein content in the above-mentioned beans ranges between 3 and 12\%. Many indigenous and underutilized beans have a much higher protein content, including the lablab bean. According to Al-Snafi [2], lablab beans have many local names, such as Hyacinth bean, Field bean, Indian bean, Sem, Simii and Bian dou. This bean can grow well under tropical and subtropical conditions. It is famous in countries such as India, Bangladesh, Africa, and Indonesia but not widely grown in others such as in Malaysia. The lablab bean is grown in Malaysia only as a backyard crop, with the current area cultivated being very low. To increase lablab bean cultivation to a commercial scale, good quality seeds should be made available locally.

This bean is a good candidate as a commercial vegetable due to the high protein content $(18-25 \%)[3,4]$. Therefore, good quality seeds must be produced locally to promote and increase lablab bean cultivation. Based on the literature, there are three cultivars of lablab bean: Rongai, with white flowers and light brown seeds when mature; Highworth, with purple flowers and black seeds; and Endurance, with white flowers and black seeds [5,6]. 
However, based on Beckett [7], the cultivar Highworth has better commercial potential due to early flowering and maturation characteristics, produces high yield, and pod maturity is more uniform compared with Rongai and Endurance. Fortunately, this cultivar is the most commonly found lablab in Malaysia, making it easier to introduce at the commercial level.

Harvesting seeds at the right time helps to ensure high seed quality. Good quality seeds are an important factor in ensuring maximum seed germination and superior seedling establishment. The lablab bean is a creeping plant with indeterminate flowering characteristics. Hence, they can have flowers, young pods and overly mature pods in one cycle. This complicates seed production, as pods must be harvested multiple times at the right maturity stage. Thus, harvesting at the correct developmental stage must be established based on a clear, simple visual indicator, such as changes in colour based on physiological responses. In addition, days after anthesis (DAA) and dry weight can be used as indicators to achieve high seed quality. Colour changes are widely used as the indicator for farmers, as legumes can change colour from early development until late harvesting. Cianzio and Ortiz [8], who studied seed development in soybean, an indeterminate crop, concluded that pod colour was the most reliable method to determine the correct time for harvesting. Therefore, an understanding of the physiological state of the seed and its association with pod colour must be established.

Seeds, upon reaching the physiological maturity stage, will undergo severance of the funiculus, which triggers a net loss in moisture. This net loss in moisture, or desiccation, is a process that initiates the switch from development to germination, as mentioned by Bewley et al. [9]. Plants with indeterminate growth characteristics will produce seeds in a wide range of maturity stages; thus, it is difficult to collect seeds at a single, optimized time. The chances of collecting relatively immature seeds can be high. Immature seeds must be at a stage that can tolerate desiccation in order for them to survive and have a similar function to mature seeds, particularly in initiating the switch from development to germination. Thus, the quality can be improved by drying, to mimic the natural desiccation of mature seeds.

Desiccation improved seed quality in Vicia sativa according to Samarah [10] and Ceiba pentandra according to Lima et al. [11]. Over-mature seeds (late harvesting) can become dormant. Thus, the objectives of this study were to determine the ideal developmental stage for harvesting pods of indeterminate lablab beans for maximum seed quality and to evaluate the effect of drying on the viability of lablab bean seeds harvested at different maturity stages.

According to Vidigal et al. [12], harvesting seeds at an ideal time can minimize seed losses and reduce the ratio of unripe seeds due to early harvest and can maximize seed germination, vigour and viability. Seed quality is said to be maximum at the end of the seed filling period [13-15], termed physiological maturity (PM) by Harington [13]. Beyond this point, the deterioration process begins, which gradually reduces the physiological quality of the seeds. However, numerous evidences is also present to show that seed quality can increase after PM. Since lablab has indeterminate growth habits, identifying the correct time to harvest is needed to avoid seed loss.

Seed development is the process that begins with the formation of the zygote and endosperm; it comprises three phases, i.e., histodifferentiation, seed filling and desiccation. There is a rapid cell division and formation of embryonic cells with a high moisture content at the first phase, histodifferentiation. The second phase is seed filling, categorized by cell expansion and accumulation of storage proteins, lipids and carbohydrates $[16,17]$. This period is also characterized by a decrease in moisture content, with an increase in seed dry weight. Therefore, when seeds reach the maximum level of seed dry weight, they are physiologically mature. The last phase is the desiccation phase. This phase involves a major loss in water that leads to dry seeds, in preparation for a quiescent period, as mentioned by Angelovici [18].

Drying seeds right after harvest is important in seed production. Yousaf et al. [19] reported that up to $30 \%$ losses can occur because of the post-harvest handling and drying 
of seeds. Seed drying is intended to reduce the seeds' moisture content to safe limits to maintain its viability and vigour during storage [20], which would otherwise deteriorate quickly due to mould growth, heating and enhanced microbial activity [21]. Orthodox seeds can be dried to low moisture content to increase longevity. While recalcitrant seeds such as Cocos nucifera will lose their viability once dried to low moisture content, lablab belongs to the orthodox seed category [22]. There are many drying methods based on the literature, such as sun, shade and vacuum drying. Nevertheless, because of the high cost of drying facilities and maintenance, seed producers in many developing countries prefer sun, shade and oven drying, due to low initial capital and ease of operation, with no complicated technological protocol.

Therefore, it is important to understand the seed development process, particularly in an indeterminate crop species, to identify important stages of seed development. Seeds harvested at the appropriate stages must be subjected to drying; hence, the most suitable and practical drying method must be established for improved seed quality.

\section{Materials and Methods}

\subsection{Materials and Field Experiments}

A completely randomized design experiment with four replications was conducted at Field 15, Faculty of Agriculture, Universiti Putra Malaysia (UPM), to determine the ideal developmental stage for the production of quality lablab bean seeds. The lablab bean cultivar Highworth was obtained from MARDI Seberang Perai, Pulau Pinang, Malaysia. A land area of $5 \mathrm{~m} \times 5 \mathrm{~m}$ was ploughed, harrowed and levelled before sowing lablab seeds. Staking with 1 inch $\times 2$ inch wood was constructed, as lablab is a climbing herbaceous crop with a total height of $8 \mathrm{ft}$. Then, seeds were directly sown in the soil and watered twice daily using a sprinkler system. Plants were arranged in a square planting system, with a planting distance of $30 \mathrm{~cm} \times 50 \mathrm{~cm}$. Silver shine was used to control weed growth around the plants. In order to control pest attacks, plants were sprayed with pesticides 3 times per season. Infected plants were sprayed with Vita Dimethoate (VITACHEM (M) SDN. BHD) $(14 \mathrm{~mL}$ for $10 \mathrm{~L}$ water) to control pests. The flowers that opened were tagged, and this was used to count the number of days after anthesis (DAA). In other words, this is the age of the pods (days) when they were harvested. Flowers were tagged upon anthesis using different coloured thread to indicate different maturity stages. Then, pods having the same-coloured thread at five days intervals-5, 10, 15, 20, 25, 30, 35, 40, 45, and 50 DAA-were harvested.

\subsection{Colour and Seed and Pod Size}

Pod and seed colour were recorded as an indicator for seed maturity stages using the Royal Horticultural Society (RHS) Colour Chart, Edition V. Lablab seeds were harvested at different maturity stages, and the pod and seed length and width were measured using Vernier callipers.

\subsection{Moisture Content and Seed Dry Weight}

Seed moisture content and seed dry weight were determined to identify the time when seeds reached physiological maturity. Then, the seeds were dried using two different drying methods; sun and oven drying. Seed moisture content was determined using the high constant temperature oven method, in accordance with ISTA [23].

$$
\text { Moisture content }(\%)=\frac{\mathrm{W} 2-\mathrm{W} 3}{\mathrm{~W} 2-\mathrm{W} 1} \times 100
$$

where

W1 = weight of the container with lid

W2 = weight of the container with lid and sample before drying

W3 = weight of the container with lid and sample after drying 


\subsection{Protein Content}

Crude protein content was determined using the Kjedahl method as described by Pearson (1970) [24], with slight modifications. Lablab bean seeds were ground using a Labtac CT410 Grinder and were ground to a fine powder. Seed powder of $0.2 \mathrm{~g}$ was weighed and transferred into a digestion tube. The sample was neutralised with one Kjedhal catalyst $\left(5 \mathrm{~g} \mathrm{~K}_{2} \mathrm{SO}_{4}+0.5 \mathrm{~g} \mathrm{CuSO}_{4} \times 5 \mathrm{H}_{2} \mathrm{O}\right)$ tablet and $6 \mathrm{~mL}$ of $98 \%$ sulphuric acid. The digestion tube was heated moderately in a fume hood at $400{ }^{\circ} \mathrm{C}$ for $1.5 \mathrm{~h}$ until the solution appeared clear. Then, the solution was allowed to cool, and all the samples were analysed for crude protein content using Kjeltec TM8400 Analyzer Unit (Foss NRISystems, Denmark).

\subsection{Germination Percentage}

Germination tests were conducted using sand as the germination media, with 25 seeds per replicate for each treatment. Germinated seeds were counted every day for up to 10 days. Seeds were considered as germinated when essential structures such as the radicle and plumule were observed. The germination percentage was calculated as per the formula below, as recommended by ISTA [23].

$$
\text { Germination percentage }=\frac{\text { number of seeds germinated }}{\text { total number of seeds }} \times 100
$$

\subsection{Germination Index (GI)}

Germination Index (GI) was calculated as specified by Kader [25]. The germination index is a parameter that combines both germination percentage and speed.

$$
\mathrm{GI}=(10 \times \mathrm{n} 1)+(9 \times \mathrm{n} 2)+(8 \times \mathrm{n} 3) \ldots \ldots
$$

where $n 1, n 2, n 3$, is the number of germinated seeds on the first, second and subsequent days until day 10

\subsection{Electrical Conductivity}

Electrical conductivity is a test to measure viability and seedling vigour [26]. A total of 10 seeds per replicate were used for each treatment and were placed in a vial containing $80 \mathrm{~mL}$ distilled water at $25^{\circ} \mathrm{C}$ for $24 \mathrm{~h}$. After $24 \mathrm{~h}$ of soaking, seeds were swirled for $10-15 \mathrm{~s}$, and the conductivity meter was dipped into the water in the cell until a stabilized reading was achieved and recorded. The mean of four plastic vials containing distilled water only (control) served as the background reading. An electrical conductivity test was calculated as per the formula below, recommended by ISTA [23].

Conductivity test $\left(\mu \mathrm{Sm}^{-1} \mathrm{~g}^{-1}\right)=\left(\frac{\text { Conductivity reading }\left(\mu \mathrm{S} \mathrm{cm} \mathrm{cm}^{-1}\right)-\text { background reading }}{\text { weight of replicate }(\mathrm{g})}\right)$

\subsection{Statistical Analysis}

Analysis of variance (ANOVA) of the data was appropriate to the experimental design, and a comparison of means was conducted using Tukey's honest significant level 0.05. All statistical analysis was carried out using Statistical Analysis System version 9.4 (SAS Institute Inc., Cary, NC, USA). Correlation analysis in the SAS program was made for pod length, pod width, seed length, seed width and moisture content.

\section{Results and Discussion}

Seed maturation is an important process during which morphological (seed size and colour), physiological (moisture content and dry weight) and functional (vigour and viability) changes occur from the time of fertilization until the seeds are ready to harvest for seed production [27]. In lablab the size of the pod increased and was a maximum at 20 DAA, with an average pod length of $81 \mathrm{~mm}$ and pod width of $15 \mathrm{~mm}$. Maximum seed size was achieved at 15 DAA, $13 \mathrm{~mm}$ seed length and $12 \mathrm{~mm}$ seed width. Then, both the 
pod and seed started to shrink, until 50 DAA. This is supported by pictures showing the physical observation of pod and seed of lablab cultivar Highworth in Table 1. Correlation analyses indicate that there is highly significant correlation between the moisture content with seed width and no significant correlation between seed length, pod length and pod width, as shown in Table 2.

Table 1. Size of pod, seed and colour of lablab cultivar Highworth at different maturity stages.

\begin{tabular}{|c|c|c|c|c|c|c|c|c|c|c|}
\hline & & & Pod & & & & & Seed & & \\
\hline DAA & $\begin{array}{c}\text { Pod } \\
\text { Length } \\
(\mathrm{mm})\end{array}$ & $\begin{array}{c}\text { Pod } \\
\text { Width } \\
(\mathrm{mm})\end{array}$ & $\begin{array}{c}\text { No. } \\
\text { RHS2015 }\end{array}$ & Colour & Pictures & $\begin{array}{l}\text { Seed } \\
\text { Length } \\
(\mathrm{mm})\end{array}$ & $\begin{array}{c}\text { Seed } \\
\text { Width } \\
(\mathrm{mm})\end{array}$ & $\begin{array}{c}\text { No. } \\
\text { RHS2015 }\end{array}$ & Colour & Pictures \\
\hline 5 & $66.15 \mathrm{~d}$ & $9.69 \mathrm{~d}$ & 144B & $\begin{array}{l}\text { Strong } \\
\text { Yellow } \\
\text { Green }\end{array}$ & $m$ & $4.91 \mathrm{~d}$ & $1.97 \mathrm{~d}$ & $144 \mathrm{~A}$ & $\begin{array}{l}\text { Strong } \\
\text { Yellow } \\
\text { Green }\end{array}$ & \\
\hline 10 & 78.08abc & $12.15 \mathrm{abc}$ & $145 \mathrm{~A}$ & $\begin{array}{l}\text { Strong } \\
\text { Yellow } \\
\text { Green }\end{array}$ & & $12.21 \mathrm{ab}$ & $7.12 \mathrm{c}$ & $144 \mathrm{C}$ & $\begin{array}{l}\text { Strong } \\
\text { Yellow } \\
\text { Green }\end{array}$ & \\
\hline 15 & 78.47ab & 13.27ab & $147 \mathrm{C}$ & $\begin{array}{c}\text { Moderate } \\
\text { Yellow } \\
\text { Green }\end{array}$ & & $13.35 a$ & $12.45 a$ & N144C & $\begin{array}{l}\text { Strong } \\
\text { Yellow } \\
\text { Green }\end{array}$ & \\
\hline 20 & $81.82 \mathrm{a}$ & $15.00 \mathrm{a}$ & 148D & $\begin{array}{c}\text { Moderate } \\
\text { Yellow } \\
\text { Green } \\
\text { Pale }\end{array}$ & & $13.56 a$ & $9.02 \mathrm{c}$ & $200 B$ & $\begin{array}{c}\text { Dark } \\
\text { Greyish } \\
\text { Brown }\end{array}$ & \\
\hline 25 & 73.29abcd & $10.66 \mathrm{~cd}$ & N 138C & $\begin{array}{l}\text { Greenish } \\
\text { Yellow } \\
\text { Light }\end{array}$ & & $11.52 b c$ & $7.74 \mathrm{c}$ & $202 \mathrm{~A}$ & Black & \\
\hline 30 & 72.55abcd & $10.71 \mathrm{~cd}$ & 177B & $\begin{array}{l}\text { Reddish } \\
\text { Brown } \\
\text { Dark }\end{array}$ & $\infty$ & $10.27 \mathrm{~cd}$ & $7.041 \mathrm{c}$ & $203 C$ & Black & \\
\hline 35 & 72.54abcd & $10.35 \mathrm{~cd}$ & N199B & $\begin{array}{l}\text { Greyish } \\
\text { Yellowish } \\
\text { Brown }\end{array}$ & & $11.17 \mathrm{bc}$ & $7.93 b c$ & $203 C$ & Black & \\
\hline 40 & $71.13 \mathrm{bcd}$ & $10.37 \mathrm{~cd}$ & $165 \mathrm{~A}$ & $\begin{array}{c}\text { Moderate } \\
\text { Brown }\end{array}$ & & $11.38 \mathrm{bc}$ & $7.29 c$ & $203 C$ & Black & \\
\hline 45 & $68.51 \mathrm{~cd}$ & $9.05 \mathrm{~d}$ & N199B & $\begin{array}{c}\text { Dark } \\
\text { Greyish } \\
\text { Yellowish } \\
\text { Brown }\end{array}$ & & $11.57 \mathrm{bc}$ & $7.89 b c$ & $203 C$ & Black & \\
\hline 50 & $67.63 \mathrm{~d}$ & $9.69 d$ & N199C & $\begin{array}{l}\text { Moderate } \\
\text { Yellowish } \\
\text { Brown }\end{array}$ & & $10.55 c$ & $7.09 c$ & $203 C$ & Black & \\
\hline
\end{tabular}

f-test $\quad * * * *$

** Indicates highly significant difference at $p<0.05$; Means with same letter vertically in each column are not significantly different at $p<0.05$ using Tukey's test.

The colour of the pod shows changes, from strong yellow-green at 5 DAA and then slowly turning to a light reddish-brown at 30 DAA. For the external visual characteristics, the seeds from the early stage (5-15 DAA) had shiny and smooth surfaces, while seeds at 30-50 DAA were black in colour, with a non-shiny surface as summarized in Table 1 . The seed size was smaller after undergoing the desiccation process. The increase in seed size is attributed to the higher food reserve and respiratory rate, as stated by Massimi [28].

Figure 1 shows that seed moisture content decreased with an increment in seed dry weight from early development stages to late maturity stages. An increase in seed size at the early stage and the significant decrease of moisture content at the end of the maturation process is mentioned by Barnwal et al. [29] and also has been reported for okra [30] and 
soybean seeds [31]. In relation to maturation stages, pod colour can be used as a visual indicator to establish the ideal time for harvesting [32,33]. The pods were green from early development until 20 DAA and then turned to greenish-yellow. Around 30 DAA, the pod colour turned from light reddish-brown to dark greyish yellow-brown. It is presumed that the change in colour could be due to the changes in the fruits' internal tissue, while the brown appearance may be associated with chlorophyll degradation and synthesis of pre-existing pigment, responsible for the characteristic colour for each plant species [34]. Therefore, the pod colour of lablab is suitable to be used as an easy indicator for establishing the ideal harvesting time in seed production: when the colour turned from light reddish-brown (30 DAA) to dark greyish yellow-brown (35 DAA).

Table 2. Correlation (r) coefficients between pod length, pod width, seed length, seed width and moisture content of lablab cultivar Highworth.

\begin{tabular}{lccccc}
\hline & $\begin{array}{c}\text { Pod Length } \\
(\mathbf{m m})\end{array}$ & $\begin{array}{c}\text { Pod Width } \\
(\mathbf{m m})\end{array}$ & $\begin{array}{c}\text { Seed Length } \\
(\mathbf{m m})\end{array}$ & $\begin{array}{c}\text { Seed Width } \\
(\mathbf{m m})\end{array}$ & $\begin{array}{c}\text { Moisture } \\
\text { Content }\end{array}$ \\
\hline $\begin{array}{c}\text { Pod Length } \\
(\mathrm{mm})\end{array}$ & 1.00000 & $0.77313^{* *}$ & $0.58436^{* *}$ & $0.54476^{* *}$ & $0.27337 \mathrm{~ns}$ \\
$\begin{array}{c}\text { Pod Width } \\
(\mathrm{mm})\end{array}$ & 1.00000 & $0.56144^{* *}$ & $0.54128^{* *}$ & $0.39670^{* *}$ \\
$\begin{array}{c}\text { Seed Length } \\
(\mathrm{mm})\end{array}$ & & 1.00000 & $0.88549^{* *}$ & $-0.24677 \mathrm{~ns}$ \\
$\begin{array}{c}\text { Seed Width } \\
(\mathrm{mm})\end{array}$ & & & 1.00000 & $-0.15273 \mathrm{~ns}$ \\
$\quad \begin{array}{l}\text { Moisture } \\
\text { content }\end{array}$ & & & & 1.00000 \\
\hline$*$ indicates highly significant differences at $p \leq 0.05 ;$ ns indicates no significant differences. &
\end{tabular}

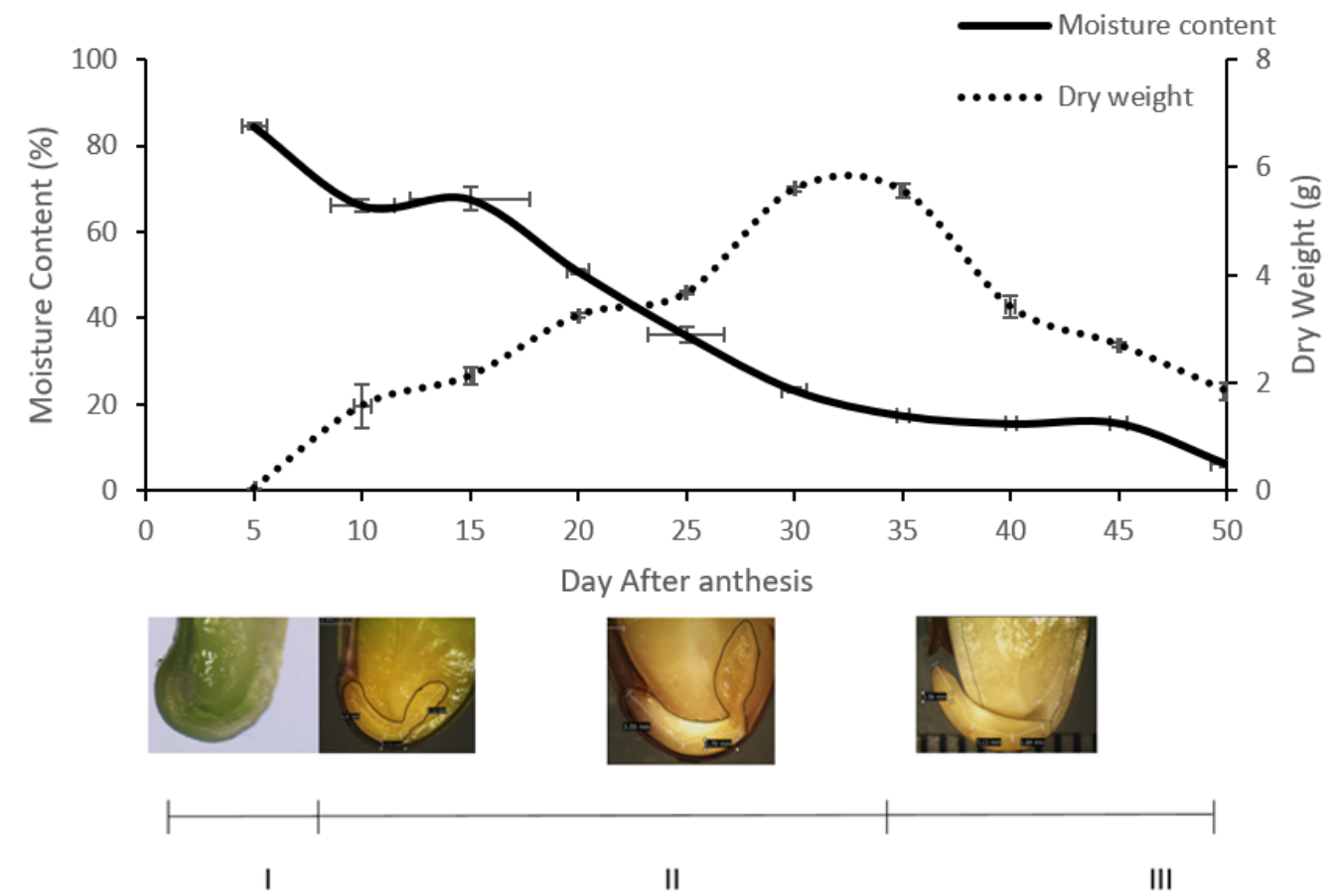

Figure 1. Moisture content and seed dry weight and transition of external embryo shape for lablab cultivar Highworth during maturity stages. The histodifferentiation (I), seed filling (II) and desiccation (III) phase are indicated at the bottom.

The moisture content was $80.78 \%$ at 5 DAA. This is due to the mobilization of water at the early phase when water is actively mobilized into the seeds. The potential water binding sites at the molecular level are saturated, and solvent water is available for biochemical 
activities to allow cell division and growth [9]. Moisture content is high at $80 \%$, because the nucleic acid and protein are still undergoing synthesis and have liquid water being pulled into the capillaries and structure. Thus, it can generate sufficient tension to retain water in seeds, as mentioned by Bewley et al. [9]. At this stage, plant embryogenesis begins with a globular shape and is mainly filled with liquid endosperm (Figure 1I). At 15 DAA, the embryo shifts into a heart shape and torpedo shape at 25 DAA (Figure 1II). At 30 DAA, the moisture content drops to $27.3 \%$ and continues to drop until $50 \mathrm{DAA}$, to $6.22 \%$. The seeds attain maximum seed dry weight at $30 \mathrm{DAA}$, at $4.478 \mathrm{~g} / 10$ seeds, and embryos start to elongate the external shape, as shown in Figure 1III. The cotyledon begins to bend, and the embryo elongates, with a complete forming of the mature embryo. Seed moisture content starts to decrease because of the utilization of water in various metabolic activities and the removal of water by the desiccation of the surrounding environment, as stated by Gurusamy and Thiagarajan [35].

The seed dry weight increases gradually, and the peak is obtained at 30 DAA. The highest seed dry weight can be an indicator of physiological maturity (PM) and can be used to obtain high seed quality, as mentioned by Browne [36] and Harington [13]. Seeds at 30 DAA recorded maximum seed dry weight, with no further increase, presumably due to the severance of the funiculus, causing a cessation of the translocation of soluble substances into the seeds. At this stage, the embryo expended the cotyledon without cell division, and became a matured embryo, developing shoot and root apical meristem. According to the study by Das and Fakir [37] on lablab beans (DS-52 and DS 106 genotypes), PM is achieved around 33 days after flowering (DAF), when seed dry weight is $7.61 \mathrm{~g} / \mathrm{pod}$ for DS-52 genotypes and 7.17 g/pod for DS-106 gentoypes. Therefore, the variation of PM in days could be due to the difference of genotype, location and growing conditions, as stated by Das and Fakir [37].

Protein content showed significant differences at different maturity stages during seed development. The protein was highest at $10 \mathrm{DAA}$, at $28.5 \%$, and then decreased until 50 DAA, as shown in Figure 2. The percentage of crude protein decreased until 50 DAA due to the utilization of protein for pod growth, in conjunction with the increase of starch and energy content [38,39]. This result is in line with studies by Hill and Breidenbach [40] and Siddique and Wright [41]; they also found that seed protein content increased very rapidly in the early development stage of soybean during seed development and decreased afterward, possibly due to the onset of seed desiccation.

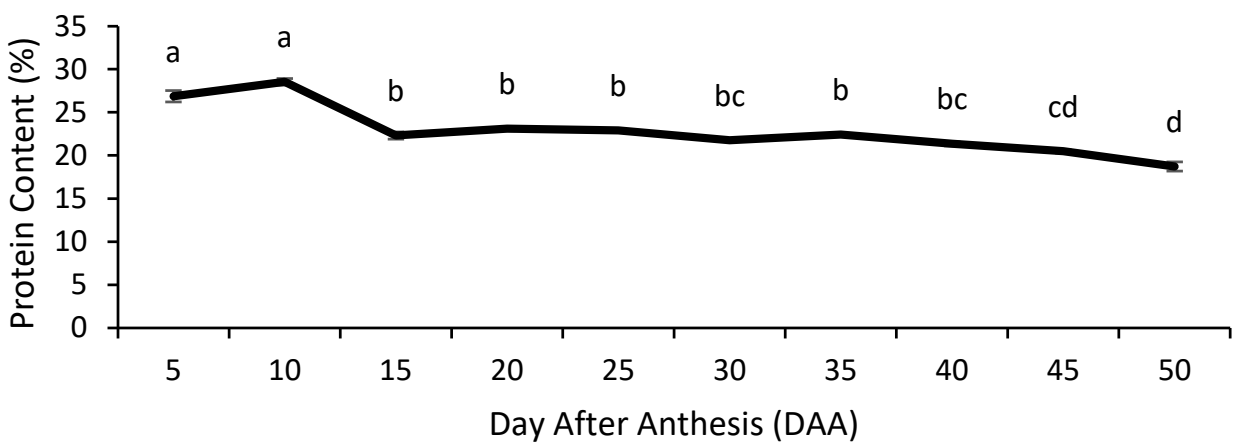

Figure 2. The protein content of lablab bean seed at different maturity stages. Means with different letters $(\mathrm{a}, \mathrm{b}, \mathrm{c}, \mathrm{d})$ were significantly varied at $p<0.05$ based on Tukey's test.

\subsection{Effect of Maturity Stages and Different Drying Methods on Germination Percentage and Germination Index}

To ensure successful crop production and seedling establishment, germination percentage should be included as an important parameter, as noted by Almansouri [42]. A good drying method is important to ensure seed quality in the form of germination percentage and speed, as presented in Figure 3. Data are means of triplicate measurements, and bars indicate the standard error. 


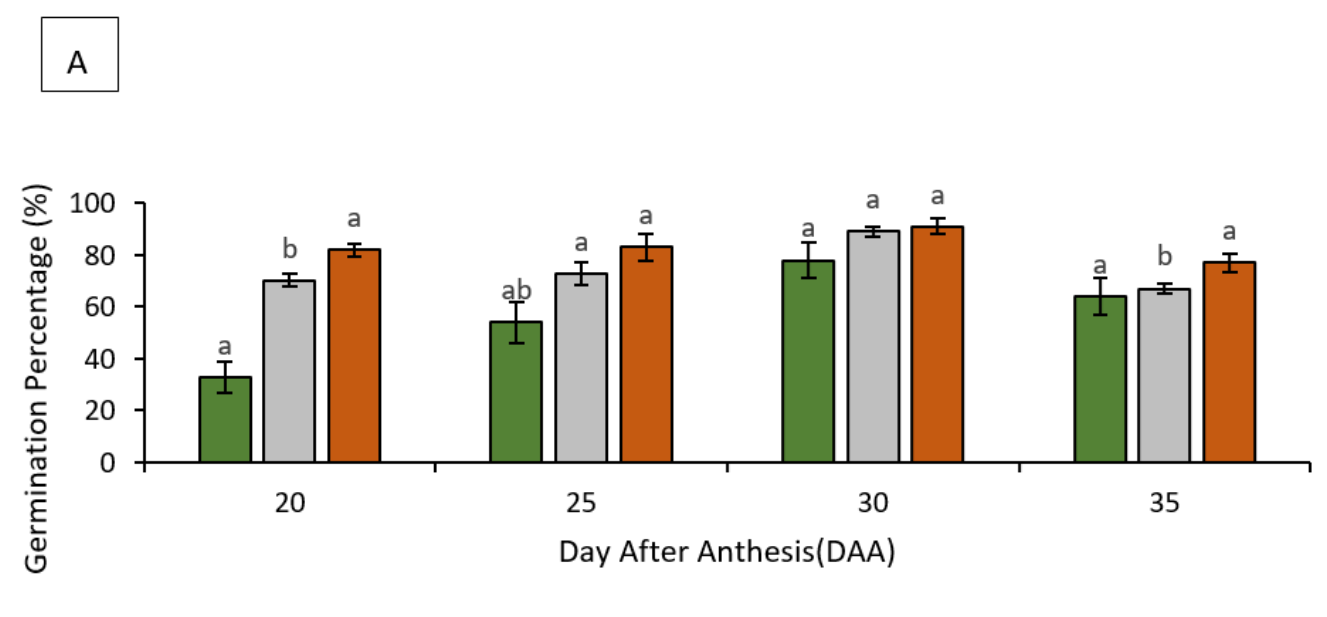

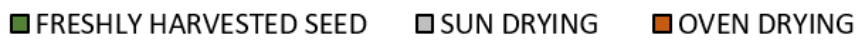

B

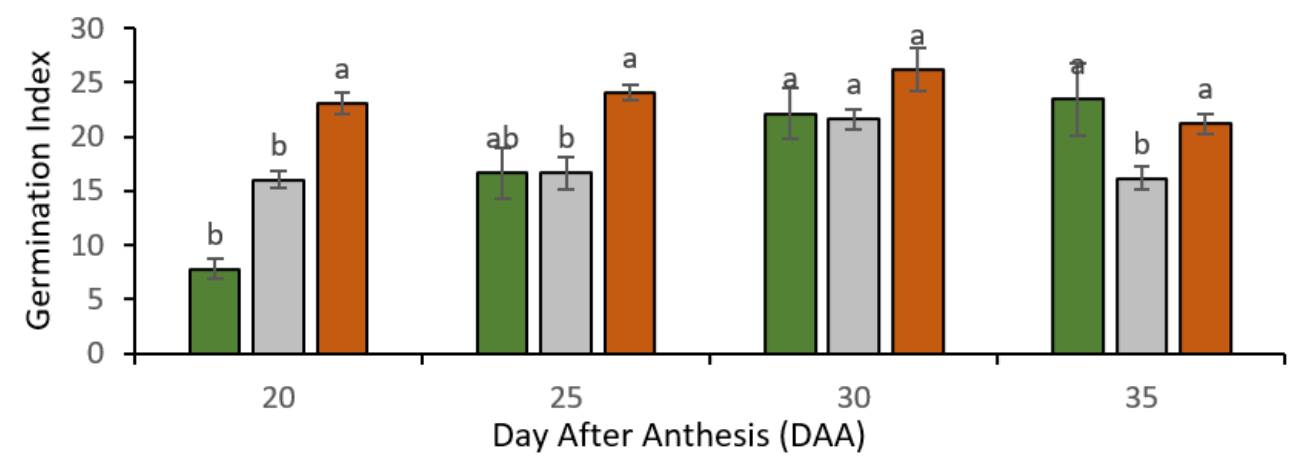

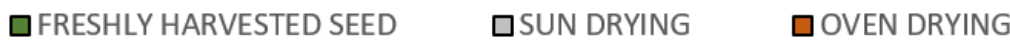
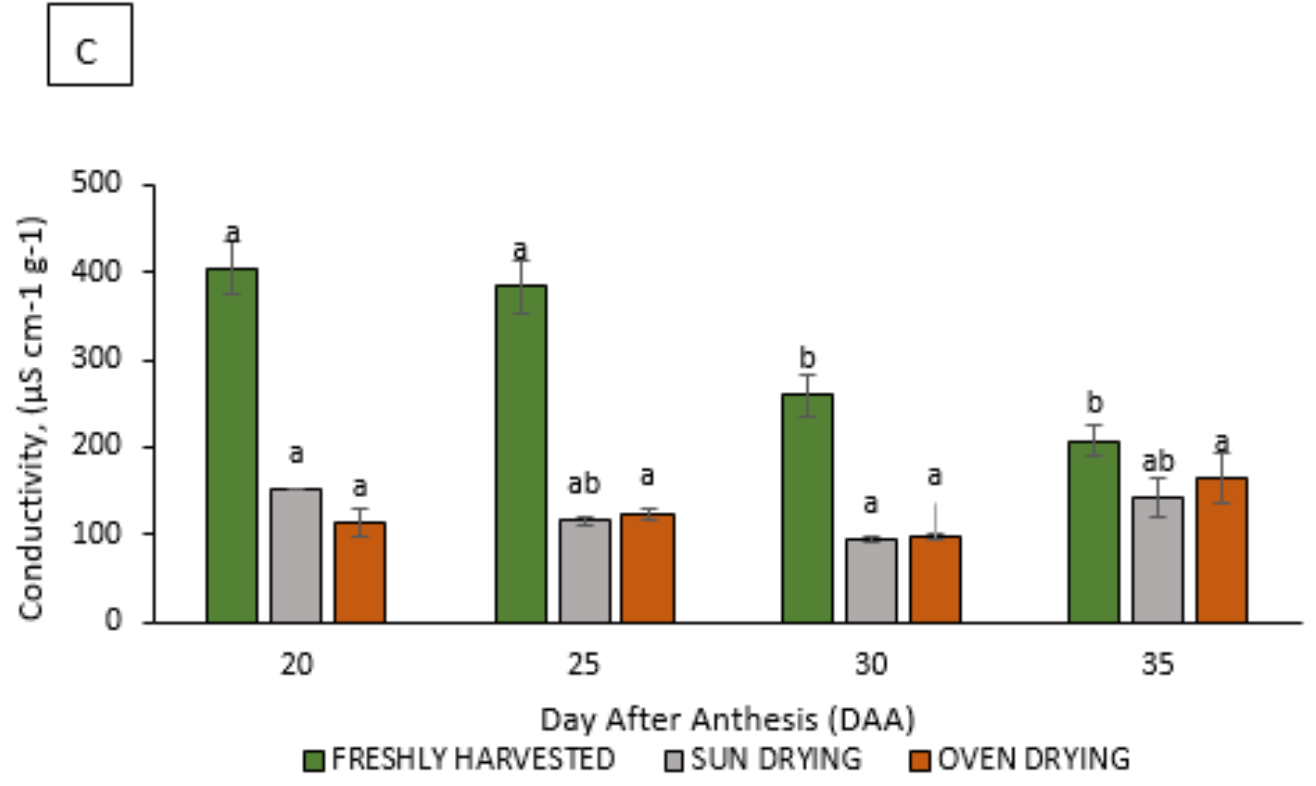

Figure 3. Seed Germination Percentage (A), Germination Index (B), Electrical Conductivity (C). Means with a different letters $(\mathrm{a}, \mathrm{b}, \mathrm{c})$ show significant differences at $p<0.05$ based on Tukey's test. 
At 20 DAA, seeds were immature and had only 33\% germination; however, drying using an oven improved germination to $82 \%$. Several researchers have reported that drying, particularly slow drying, can enhance the ability to tolerate desiccation and improve germination $[17,31]$. The improvement in germination is due to the improvement of the cell membrane integrity.

Seeds harvested at 30 DAA naturally developed the ability to germinate, recording germination up to $78 \%$. Similar results have been noted in many crops, with high germination being recorded at physiological maturity. When seeds at this stage of development were subjected to sun and oven drying, they recorded a high percentage, 89\% and 91\%, respectively. It is very interesting to note that lablab bean seeds can achieve maximum germination percentage and germination index, irrespective of the drying method used. Based on Kader [25], the higher the germination index (GI) value, the higher the per-centage and rate of germination. Even though there was no significant effect on germination percentage and germination index with different drying methods, it was shown that drying types can enhance germination percentage as well as the germination index of lablab bean seeds. From this data, we can see that the drying methods (sun and oven) can be equally good in reducing seed moisture content in maintaining the viability of the seeds. Other crops also showed a similar response to drying, improving seed quality before physiological maturity; these include sorghum [43], peanut [44], and carrot seeds [45].

Seed qualities, such as high germination percentage, viability, vigour, storability and germination speed can be influenced by the harvesting stage. Studies by Wright and Siddique [46] on the viability and vigour of Pisum sativum seeds achieved a maximum germination percentage of $96 \%$ when seeds were dried in an oven at $40{ }^{\circ} \mathrm{C}$. The present findings also support Enoch et al. [47], who concluded that the germination percentage of Bambara nut, cowpea and maize seeds that underwent sun drying had improved germination $(>90 \%)$ at all maturity stages compared with shade and room drying.

\subsection{Effect of Maturity Stages and Different Drying Methods on Electrical Conductivity (EC)}

The lowest value of EC was obtained at 30 DAA with the oven and sun drying method, showing a reading of $94.23 \mu \mathrm{S} \mathrm{cm} \mathrm{cm}^{-1} \mathrm{~g}^{-1}$ and $96.52 \mu \mathrm{S} \mathrm{cm}^{-1} \mathrm{~g}^{-1}$, respectively, which increased thereafter. Less electrolyte leakage was observed at $30 \mathrm{DAA}$, which could be attributed to good cell membrane integrity; intactness was able to minimize seed leakage and increase in the deposition of storage reserves [9]. According to Kanmegne et al. [48], electrolyte leakage from tissue can be used to indicate the effectiveness of membranes as barriers to solute diffusion. Electrolyte leakage increasing (oven and sun drying) after 30 DAA might be due to the seeds being dried below the critical moisture content; it reached the maximum value at the lethal moisture content level [49]. This is probably due to cell membrane damage during excessive desiccation. The excessive dehydration of seeds beyond the moisture level will increase the concentration of leaked solutes and cause the seeds to lose their viability. Low values of EC indicate that membranes had greater organization and consequently have high seed vigour. This is also confirmed by increasing germination percentage and positive correlation between EC and germination index, as stated in Table 3, which is an indicator of high seed quality. This finding was similar and consistent with the results obtained by Silva et al. [50] for Jatropha curcas and Solanum melangena L. [51] and Vidigal et al. [12] for Capsicum annuum L. seeds. 
Table 3. Correlation (r) coefficients between germination percentage, germination index and electrical conductivity of lablab cultivar Highworth.

\begin{tabular}{|c|c|c|c|}
\hline & $\begin{array}{c}\text { Germination } \\
\text { Percentage (\%) }\end{array}$ & $\begin{array}{l}\text { Germination } \\
\text { Index }\end{array}$ & $\begin{array}{c}\text { Electrical } \\
\text { Conductivity } \\
\left(\mu S \mathrm{~cm}^{-1} \mathrm{~g}^{-1}\right)\end{array}$ \\
\hline Germination percentage (\%) & 1.00000 & $0.15395 \mathrm{~ns}$ & $0.08531 \mathrm{~ns}$ \\
\hline Germination index & & 1.00000 & $0.78234^{* *}$ \\
\hline $\begin{array}{l}\text { Electrical conductivity } \\
\qquad\left(\mu \mathrm{S} \mathrm{cm}^{-1} \mathrm{~g}^{-1}\right)\end{array}$ & & & 1.00000 \\
\hline
\end{tabular}

\section{Conclusions}

The study showed that lablab bean pods attained physiological maturity at 30 DAA when the seed moisture content was $27 \%$. At this stage, the pods changed colour from pale greenish-yellow to light reddish-brown and resulted in the highest germination percentage $(78 \%)$. Drying using an oven at $30{ }^{\circ} \mathrm{C}$ for $72 \mathrm{~h}$ reduced the moisture content to $14 \%$. This also improved germination from 78 to $91 \%$.

In the present study, harvested immature seeds subjected to oven drying had improved germination percentage because of the enhanced ability to tolerate desiccation. Lablab seeds attained maximum dry weight, germination, and vigour at 30 days after an-thesis (DAA). Based on the DAA, the best physical indicator that can be recommended for lablab beans is when the pods change to a light reddish-brown. Upon harvest, the lablab bean should be subjected to drying using either sun or oven drying to reduce moisture content for the next step, which is storage. Lablab beans have up to $91 \%$ germination after oven drying and $89 \%$ germination after sun drying. However, in terms of germination speed and membrane integrity (based on electrolyte leakage), seeds harvested at 30 DAA and dried using an oven showed better results compared with sun drying.

Author Contributions: Conceptualization, N.F.H.H. and U.R.S.; methodology, N.F.H.H.; formal analysis, N.F.H.H.; investigation, N.F.H.H.; data curation, N.F.H.H. and U.R.S.; writing-original draft preparation, N.F.H.H.; writing-review and editing, N.F.H.H., U.R.S. and M.M.Y.; visualization, M.M.Y. and U.R.S.; supervision, U.R.S. and M.M.Y.; project administration, N.F.H.H. and U.R.S.; funding acquisition, U.R.S. All authors have read and agreed to the published version of the manuscript.

Funding: This research received no external funding.

Data Availability Statement: The data presented in this study are available on request from the corresponding author. The data are not publicity available.

Acknowledgments: The authors would like to thank the Graduate Research Fellowship (GRF) from Universiti Putra Malaysia for their financial support of the study.

Conflicts of Interest: The authors declare no conflict of interest.

\section{References}

1. Rudrappa, U. Winged Bean Nutrition Facts. Available online: https://www.nutrition-and-you.com/mung-bean.html (accessed on 20 September 2019).

2. Al-Snafi, P.D.A.E. The pharmacology and medical importance of Dolichos lablab (Lablab purpureus)—A review. IOSR J. Pharm. 2017, 7, 22-30. [CrossRef]

3. Subagio, A. Characterization of hyacinth bean (Lablab purpureus (L.) sweet) seeds from Indonesia and their protein isolate. Food Chem. 2006, 95, 65-70. [CrossRef]

4. Naeem, M.; Shabbir, A.; Ansari, A.; Aftab, T.; Khan, M.; Uddin, M. Hyacinth bean (Lablab purpureus L.)-An underutilised crop with future potential. Sci. Hortic. 2020, 272, 109551. [CrossRef]

5. Maass, B.L.; Knox, M.R.; Venkatesha, S.C.; Angessa, T.T.; Ramme, S.; Pengelly, B.C. Lablab purpureus-A crop lost for Africa. Trop. Plant Biol. 2010, 3, 123-135. [CrossRef]

6. $\quad$ Simonyan, K.J.; Yiljep, Y.D.; Oyatoyan, O.B.; Bawa, G.S. Effect of moisture content on some physical properties of Lablab purpureus sweet seeds. Agric. Eng. Int. 2009, 11, 1279. 
7. Beckett, C. Dolichos Lablab: A Legume that Feeds People, Animals and the Soil. Available online: https://www.echocommunity. org/en/resources/c82a56e2-82a2-4ac1-9873-c4bff04e1480 (accessed on 9 January 2020).

8. De Cianzio, S.R.; Ortiz, C.E. A visual indicator for harvest of immature viable seed of indeterminate soybean genotypes. J. Agric. Univ. Puerto Rico 1993, 77, 33-44. [CrossRef]

9. Bewley, J.D.; Bradford, K.J.; Hilhorst, H.W.M.; Nonogaki, H. Seeds: Physiology of Development, Germination and Dormancy, 3rd ed.; Springer: New York, NY, USA, 2013.

10. Samarah, N.H. Effect of air-drying immature seeds in harvested pods on seed quality of common vetch (Vicia sativa L.). N. Z. J. Agric. Res. 2006, 49, 331-339. [CrossRef]

11. Lima, M.D.V.; Ellis, R.H.; Hong, T.D.; Ferraz, I.D.K. Drying method influences the development of germinability, dessication tolerance and subsequent longevity of immature seeds of sumaúma (Ceiba pentandra (L.) Gaertn. [Bombacaceae]). Seed Sci. Technol. 2005, 33, 147-156. [CrossRef]

12. Vidigal, D.d.S.; Dias, D.C.F.d.S.; Dias, L.A.d.S.; Finger, F.L. Changes in seed quality during fruit maturation of sweet pepper Sci. Agric. 2011, 68, 535-539. [CrossRef]

13. Harington, J. Seed Storage and longevity. In Seed Biology; Kozlowski, T.T., Ed.; Academic Press: New York, NY, USA, 1972; p. 145

14. Tekrony, D.M.; Hunter, J.L. Effect of seed maturation and genotype on seed vigor in maize. Crop Sci. 1995, 35, 857-862. [CrossRef]

15. Tekrony, D.M.; Egli, D.B. Accumulation of seed vigour during development and maturation. In Basic and Applied Aspects of Seed Biology; Springer: Dordrecht, The Netherlands, 1997; pp. 369-384.

16. Bewley, J.D. Black Seeds: Physiology of Development and Germination, 2nd ed.; Springer: New York, NY, USA, 1994.

17. Kermode, A.R. Regulatory mechanisms involved in the transition from seed development to germination. Plant Sci. 1990, 9 , 155-195. [CrossRef]

18. Angelovici, R.; Galili, G.; Fernie, A.R.; Fait, A. Seed Desiccation: A Bridge between Maturation and Germination. Trends Plant Sci. 2010, 15, 211-218. [CrossRef] [PubMed]

19. Yousaf, Z.; Saleh, N.; Ramazan, A.; Aftab, A. Post harvesting techniques and maintenance of seed quality. In New Challenges in Seed Biology-Basic and Translational Research Driving Seed Technology; Intech: Rijeka, Croatia, 2016; pp. 114-135.

20. Opondo, F.B.O.K. Influence of drying method and fruit position on the motherplant on seed quality of spiderplant (Cleome gynandra L.) morphotypes from western Kenya. Adv. Appl. Sci. Res. 2011, 2, 74-83.

21. Chala, M.; Bekana, G. Review on seed process and storage condition in relation to seed moisture and ecological factor. J. Nat. Sci. Res. 2017, 7, 84-90. [CrossRef]

22. Doijode, S. Seed Storage of Horticultural Crops, 1st ed.; CRC Press: London, UK, 2001.

23. International Seed Testing Association. International Rules for Seed Testing; ISTA: Wallisellen Switzerland, 2016.

24. Pearson, D. The Chemical Analysis of Food, 6th ed.; Henry Edward Cox.: London, UK, 1970.

25. Kader, M.A. A Comparison of Seed Germination Calculation Formulae and the Associated Interpretation of Resulting Data. J. Proc. R. Soc. N. S. W. 2005, 138, 65-75.

26. Manju, V.; Kumar, S. Seed leachate conductivity and its correlation with the seed viability and germination of Tnau Papaya Cv. Co8 seeds stored under different environmental conditions. Int. J. Agric. Sci. Res. (IJASR) 2015, 5, 127-130.

27. Demir, E.; Balkaya, A. Seed development stages of kale (Brassica oleracea var. acephala L.) genotypes in Turkey. Hortic. Sci. 2005, 32, 147-153. [CrossRef]

28. Massimi, M. Impact of seed size on seeds viability, vigor and storability of Hordeum vulgare (L.). Agric. Sci. Dig. Res. J. 2018, 38, 62-64. [CrossRef]

29. Barnwal, A.K.; Pal, A.K.; Tiwari, A.; Pal, S.; Singh, A.K. Effect of picking stages on fruit and seed development in Okra (Abelmoschus esculentus (L.) Moench) cultivars Kashi Pragati and Kashi Kranti. Int. J. Agric. Environ. Biotechnol. 2017, 10, 695. [CrossRef]

30. Gaikwad, A.P. Effect of time of harvesting on physical and chemical properties of soybean (Glycine max M.) seed. Int. J. Curr. Microbiol. Appl. Sci. 2017, 28, 187-190. [CrossRef]

31. Weerasekara, I.; Sinniah, U.R.; Namasivayam, P.; Nazli, M.H.; Abdurahman, S.A.; Ghazali, M.N. The Influence of Seed Production Environment on Seed Development and Quality of Soybean (Glycine max (L.) Merrill). Agronomy 2021, 11, 1430. [CrossRef]

32. Elias, S.G.; Copeland, L.O. Physiological and harvest maturity of canola in relation to seed quality. Agron. J. 2001, 93, 1054-1058. [CrossRef]

33. Wang, Y.; Mu, C.; Hou, Y.; Li, X. Optimum harvest time of Vicia cracca in relation to high seed quality during pod development. Crop Sci. 2008, 48, 709-715. [CrossRef]

34. De Lima, C.R.d.; Bruno, R.d.L.A.; da Silva, K.d.R.G.; Pacheco, M.V.; Alves, E.U.; de Andrade, A.P. Physiological maturity of fruits and seeds of Poincianella pyramidalis (Tul.) L.P. Queiroz. Rev. Bras. De Sementes 2012, 34, 231-240. [CrossRef]

35. Gurusamy, C.; Thiagarajan, C.P. The pattern of seed development and maturation in cauliflower (Brassica oleracea L. var. botrytis). Phyton-Ann. Rei Bot. 1998, 38, 259-268.

36. Browne, C.L. Identification of physiological maturity in sunflowers Helianthus annuus. Aust. J. Exp. Agric. 1978, 18, 282-286. [CrossRef]

37. Das, S.S.; Fakir, M.S.A. Pod growth and seed composition in two genotypes of Lablab Purpureus. Legume Res. Int. J. 2014, 37, 306-310. [CrossRef]

38. Nitsch, J.P. The physiology of fruit growth. Annu. Rev. Plant Physiol. 1953, 4, 199-236. [CrossRef] 
39. Darby, H.M.; Lauer, J.G. Harvest date and hybrid influence on corn forage yield, quality and preservation. Agron. J. 2002, 94, 281-289. [CrossRef]

40. Hill, J.E.; Breidenbach, R.W. Proteins of soybean seeds. Plant Physiol. 1974, 53, 747-751. [CrossRef]

41. Siddique, A.B.; Wright, D. Effects of time of harvest at different moisture contents on seed fresh weight, dry weight, quality (viability and vigour) and food reserves of peas (Pisum sativum L.). Asian J. Plant Sci. 2003, 2, 983-992. [CrossRef]

42. Almansouri, M.; Kinet, J.; Lutts, S. Effect of salt and osmotic stresses on germination in durum wheat (Triticum durum Desf.). Plant Soil 2001, 231, 12. [CrossRef]

43. Hoekstra, F.A.; Golovina, E.A.; Buitink, J. Mechanism of plant desiccation tolerance. Trends Plant Sci. 2001, 6, 431-438. [CrossRef]

44. Krzyzanowski, F.C.; West, S.H.; Neto, J.D.B.F. Drying peanut seed using air ambient temperature at low relative humidity. Rev. Bras. De Sementes 2006, 28, 1-5. [CrossRef]

45. Tucker, W.G.; Gray, D. The effect of seed drying and gibberellin treatment on the germination performance of developing carrot seed. Plant Growth Regul. 1986, 4, 363-370. [CrossRef]

46. Wright, D.; Siddique, A.B. Effects of different drying time and temperature on moisture percentage and seed quality (viability and vigour) of pea Seeds (Pisum sativum L.). Asian J. Plant Sci. 2003, 2, 976-982. [CrossRef]

47. Enoch, A.D.; Ehsan, D.M.; Sognon, V.; Florent, E. Investigating the effects of low input drying procedures on maize (Zea mays L.), cowpea (Vigna unguiculata L.) and bambara groundnut (Vigna subterranea (L.) Verde.) Seed quality in Benin. Plant Genet. Resour. Newsl. 2004, 140, 1-8.

48. Kanmegne, G.; Anouma, M.; Fotso, A.; Mbouobda, H.; Mbibong, D.; Omokolo, D. Germination of Cola anomala (K. Shum.) Shott and Endl seeds: Effects of provenance, substrate and dehydration. Int. J. Biol. Chem. Sci. 2015, 9, 1171-1180. [CrossRef]

49. Panza, V.; Láinez, V.; Maldonado, S.; Maroder, H.L. Effects of desiccation on Euterpe edulis Martius seeds. Biocell 2008, 31, 383-390. [CrossRef]

50. Da Silva, L.J.; Dias, D.C.F.d.S.; Oliveira, G.L.; da Silva, R.A. The effect of fruit maturity on the physiological quality and conservation of Jatropha curcas seeds. Rev. Cienc. Agron. 2017, 48, 487-495. [CrossRef]

51. Martins, D.C.; Vilela, F.K.J.; Guimarães, R.M.; Gomes, L.A.A.; da Silva, P.A. Physiological maturity of eggplant seeds. Rev. Bras. De Sementes 2012, 34, 534-540. [CrossRef] 